\title{
Retinal Detachment Surgery at Nepal Eye Hospital
}

\author{
Malla OK,' Shrestha S, ${ }^{1}$ Shrestha SP, ${ }^{1}$ Byanju RN, ${ }^{1}$ Karki DB ${ }^{1}$ \\ 'Department of Ophthalmology, Kathmandu Medical College, Sinamangal, Kathmandu, Nepal
}

\section{ABSTRACT}

Introduction: Retinal diseases are one of the important causes of blindness in Nepal. This study is done with objectives of finding the outcome of retinal detachment surgery.

Methods: A retrospective analysis of 110 patients who underwent retinal detachment surgery over five year period was conducted in Nepal.

Results: Retinal re-attachment was achieved in $94.4 \%$ and postoperative visual acuity of $6 / 36$ to $6 / 6$ was achieved in $52.7 \%$ (As possible risk factors, myopia was present in $34.5 \%$ ophkia in $29 \%$, trauma in $9 \%$, and lattice) degeneration was $5.4 \%$.

Conclusions: The study has shown a promising result for the retinal detachment surgery.

Key Words: retinal break, retinal detachment, scleral buckling, vitrectomy

\section{INTRODUCTION}

The 1981 blindness survey revealed retinal diseases as one of the important causes of blindness in Nepal. The incidence of rhegmatogenous retinal detachment in the general population is approximately 1 in $10,000 .^{1}$

Treatment for retinal detachment started with ignipuncture by Gonin in $1921^{2}$ followed by cryotherapy in $1930 \mathrm{~s}^{3,4}$ and photocoagulation in $1960^{5}$ for chorioretinal adhesion. Introduction of scleral buckling surgery was done in 1950s and 1960s that raised the likelihood of successful surgical outcome from less than $50 \%$ to $80 \%$ or more. ${ }^{6}$

Vitrectomy is usually done however, pneumatic retinopexy may be elected when there are small retinal breaks in the retinal detachment. ${ }^{7-9}$ Even Lincoff balloon technique ${ }^{10}$ has been used for small peripheral detachments around a single break with minimal subretinal fluid.
This study aims to review results of retinal detachment surgery during early phases of such service in Nepal.

\section{METHODS}

A retrospective study was conducted in Nepal Eye Hospital, Kathmandu from 1989 to 1994. Hospital permission was taken for the study. All the patients who presented with rhegmatogenous retinal detachment over the study period were included in the study. Patients with exudative and tractional retinal detachment were excluded from the study.

The details of name, age, sex, duration and type of symptoms and previous history of ocular trauma was noted. Data collection and statistical analysis was done by Microsoft office excel 2003.

\section{RESULTS}

Total 110 patients underwent retinal detachment surgery for rhegmatogenous retinal detachment. The 
most common age group being $51-70$ years $(40.1 \%)$ and were less common after 70 years of age $(9.1 \%)$. No cases of retinal detachment occurred before the age of 10 years (Table 1 ). Male (63.6\%) exceeded the female $(36.6 \%)$ in the study $(n=70)$.

Table 1. Distribution of patients according to age group

\begin{tabular}{lc}
\hline Age (year) & Number (\%) \\
\hline$<10$ & 0 \\
$11-30$ & $26(23.6)$ \\
$31-50$ & $30(27.3)$ \\
$51-70$ & $44(40.1)$ \\
Over 70 & $10(9)$ \\
Total & $110(100)$ \\
\hline
\end{tabular}

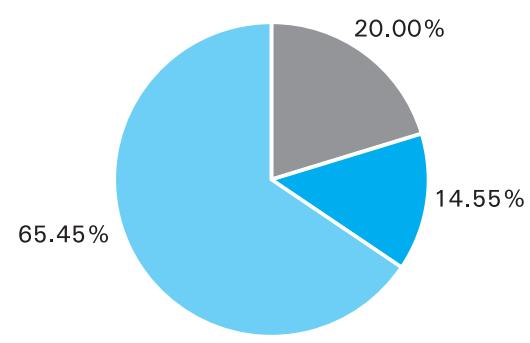

Myopia less than 6.0D $\square$ Mopia more than 6.0D $\square$ No myopia

\section{Figure 1. Distribution of myopia}

Total $34.55 \% \quad(n=38)$ of patients with retinal detachment were myopic (Figure 1). Among them, myopia <6 Diopter was present in $20 \%$ and myopia $>6$ was present in $14.45 \%(n=16)$.

Regarding the status of the lens, $71 \%(n=78)$ were phakic, $21.8 \%(n=24)$ were post ICCE aphakic, $5.4 \%$ $(n=6)$ were post ECCE aphakic and only $1.8 \%(n=2)$ were pseudophakic (Table 2).

Table 2. Distribution of status of lens

\begin{tabular}{|c|c|c|}
\hline Status of lens & & Number (\%) \\
\hline Pseudophakic & & $2(1.8)$ \\
\hline \multirow{2}{*}{ Aphakic } & ECCE & $6(5.4)$ \\
\hline & ICCE & $24(21.8)$ \\
\hline Phakic & & 78 (71) \\
\hline Total & & $110(100)$ \\
\hline
\end{tabular}

Possible risk factors for retinal detachment was noted in $78.2 \%(n=86)$ in which myopia comprised $34.5 \%$ $(n=38)$ followed by aphakia $29 \%(n=32)$, trauma $9 \%$ $(n=10)$ and lattice degeneration 5.4\% $(n=6)$ (Table 3).
Table 3. Distribution of possible etiology of retinal detachment

\begin{tabular}{ll}
\hline Possible Etiology of RD & Number (\%) \\
\hline Aphakia & $32(29)$ \\
Myopia & $38(34.5)$ \\
Trauma & $10(9)$ \\
Vitreoretinal degeneration (lattice) & $6(5.4)$ \\
Undetermined & $24(21.8)$ \\
Total & $110(100)$ \\
\hline
\end{tabular}

The presenting visual acuity of perception of hand motions (HM) was present in almost half of the cases (49.1\%, $n=54)$ while $14.5 \%$ cases $(n=16)$ could perceive light only and $5.5 \%$ of the cases presented with visual acuity $6 / 36$ or better. However, postoperative acuity of $6 / 36$ or better was present in $52.7 \%$ (Table 4).

Table 4. Distribution of preoperative and postoperative visual acuity

\begin{tabular}{lll}
\hline Visual Acuity & $\begin{array}{l}\text { Pre-Operative } \\
\text { Number (\%) }\end{array}$ & $\begin{array}{l}\text { Post-Operative } \\
\text { Number (\%) }\end{array}$ \\
\hline $\mathrm{PL}$ & $16(14.5)$ & $2(1.8)$ \\
$\mathrm{HM}$ & $54(49.1)$ & $20(18.2)$ \\
$\mathrm{CF}-1 / 60$ & $20(18.2)$ & $4(3.6)$ \\
$2 / 60-6 / 60$ & $14(12.7)$ & $26(23.6)$ \\
$6 / 36-6 / 18$ & $4(3.6)$ & $48(43.6)$ \\
$6 / 12-6 / 6$ & $2(1.8)$ & $10(9.1)$ \\
Total & $110(100)$ & $110(100)$ \\
\hline
\end{tabular}

Single $U$ tear was responsible for retinal detachment in almost half of the cases $(51 \%, n=56)$. Retinal dialysis was noted in only $3.6 \%(n=4)$. However, no retinal breaks could be seen in $5.5 \%(n=6)$. Single or multiple retinal holes were responsible in $32.6 \%(n=36)$ cases.

Retinal breaks were located in suprotemporal quadrant in more than half of the cases $(55.22 \%, n=74)$ followed by inferotemporal quadrant $(26.87 \%, n=36)$ while inferonasal quadrant was least common site for retinal breaks $(2.98 \%, n=4)$. Some patients had more than one break in the retina and 2 patients had secondary macular hole (Table 5).

Table 5. Distribution of position of breaks

\begin{tabular}{ll}
\hline Position of breaks & Number (\%) \\
\hline Superotemporal & $74(55.22)$ \\
Inferotemporal & $36(26.87)$ \\
Superonasal & $18(13.43)$ \\
Inferonasal & $4(2.98)$ \\
Macular & $2(1.49)$ \\
Total & $134(100)$ \\
\hline
\end{tabular}


$78.2 \%(n=86)$ patients presented with partial retinal detachment and $21.8 \%(n=24)$ has total detachment. Only $1.8 \%(n=2)$ patients had attached macula at presentation (Table 6).

Table 6. Distribution of size of retinal detachment

\begin{tabular}{ll}
\hline Size of retinal detachment & Number (\%) \\
\hline Total & $24(21.8)$ \\
More than half & $50(45.4)$ \\
Less than half & $36(32.8)$ \\
Total & $110(100)$ \\
\hline
\end{tabular}

Scleral buckling was done in the form of radial plomb (20\%), circumferential plomb $(27.3 \%)$, radial plomb with encirclage(23.6\%), tyre with encirclage(9.1\%) and encirclage only(20\%). Similarly, subretinal fluid drainage was done in $94.5 \%$ of cases.

Retinal reattachment was achieved in $94.4 \%(n=106)$ patients. Post-operative visual acuity of $6 / 36$ to $6 / 6$ was achieved in $52.7 \%(n=58)$ patients.

\section{DISCUSSION}

Among 110 cases of retinal detachment treated with scleral buckling by a single surgeon over the period of five years the male female ratio was 1.7:1 in the present study. A study conducted by Wong et $\mathrm{al}^{11}$ and Jonathan et $\mathrm{al}^{12}$ also found a higher risk of rhegmatogenous retinal detachment in men than women.

Retinal detachment was found most commonly in the age group 51-70 years in the present study. Jonathan et $\mathrm{al}^{12}$ and Haimann et $\mathrm{al}^{13}$ also found an association between risk of rhegmatogenous retinal detachment and increasing age.

In the present study, $1.8 \%$ were pseudophakics and $27.2 \%$ were aphakics of which $5.4 \%$ were the ones who underwent extracapsular cataract extraction while $21.8 \%$ had undergone intracapsular cataract extraction. In a study done by Jonathan et al, pseudophakic and aphakic rhegmatogenous retinal detachments comprised $19 \%$ of the total rhegmatogenous retinal detachment cases. ${ }^{12}$

Aphakic and pseudophakic confer a moderate reduction in the rate of reattachment. Traditionally, aphakic has been associated with significant reduction in anatomic success. Rates of 85 to $95 \%$ have been achieved.

A single $\mathrm{U} /$ horseshoe tear was seen in $51 \%$ of cases in this study. However, in a study by Comer M. B et $\mathrm{al}^{14}, 76 \%$ of the retinal breaks were of horseshoe type tears while in a study by Shrestha et al, ${ }^{15} 42 \%$ had horseshoe type of retinal break.

A major determinant of postoperative visual acuity is the status of the macula. Macular detachment of any duration, even 1 day results in reduced postoperative acuity. Overall, 40 to $50 \%$ of patients with macular detachment achieve, acuity of $6 / 18$ or better postoperatively.

Certain clinical phenomenons are associated with a greatly reduced chance of success. PVR is the most common such findings, the estimates of anatomic success in the presence of PVR vary from less than $50 \%$ to more than $75 \%$.

Surgical results of retinal detachment have improved considerably in the last two decades. ${ }^{16,17}$ In the developing countries, the final reattachment rates vary from $77-87 \%$ with the use of modern technology. In a study done in India, $80 \%$ of successfully reattached retina obtained a vision of $6 / 60$ or better. ${ }^{18,19}$ In a study by Shrestha et $\mathrm{al}^{15}, 85.7 \%$ had primary surgical success rate among 42 eyes being treated. However, in our study, $96.4 \%$ had attached retina at the conclusion of the surgery. According to a study conducted by Comer $\mathrm{MB}$ et $\mathrm{al}^{14}$, vitreoretinal specialists could achieve success rate of $90 \%$ with a single procedure. ${ }^{20,21}$

Better preoperative visual acuity, fewer quadrant involvement and lack of high myopia were important prognostic factors for visual acuity in a study done by Salicone et $a^{22}$ nvolving 672 patients with retinal detachment while the duration of macular detachment had surprisingly little influence on post operative visual acuity. Most authors agree that functional success depends in part on preoperative visual acuity and patient age. The chances of restoring good vision decline with advancing age. ${ }^{23,24}$ In the present study, preoperatively $49.1 \%$ had visual acuity of hand movements while postoperatively $44 \%$ had visual acuity of $6 / 36$ to $6 / 18$ although $98.2 \%$ of patients had macular detachment at the time of presentation, $14.5 \%$ had high myopia and $67.2 \%$ had involvement of more than two quadrants. Similarly, PVR grade C1 or worse was present in $16.3 \%$ out of the total of $21.7 \%$ of cases with PVR.

Postoperative visual acuity depends on the status of the macula: whether and for how long it was detached before surgery. If the macular was detached, degeneration of photoreceptors may prevent good postoperative visual acuity. While $78 \%$ of eyes with retinal detachment sparing the macula recovered visual of $6 / 18$ or better, only $37 \%$ with detachment macular attained that level. In the present study, $98.2 \%$ of patients were found to have macula detached at the time of presentation and it was not easy for them to speculate the duration of detachment. ${ }^{25}$

In our series of 110 RRD cases, in almost all cases there was no indication of the duration of macular detachment.

Anatomical success is achieved in $96.4 \%$ of patients, who undergo retinal detachment surgery, but 
number of patients who achieve good visual acuity is comparatively less. A number of factors have been identified for poor visual recovery. It is well established fact that visual recovery may occur as long as 2 year following retinal detachment surgery and recovery is because of regeneration of retinal receptors. Visual loss could be either assigned to rearranged/misalignment of retinal receptors and in complete regeneration of retinal receptors. ${ }^{26}$

Traditionally, aphakia has been associated with a significant reduction in anatomic success. Rates of 85 to $95 \%$ have been achieved. ${ }^{25,26}$ However, in our study although $29 \%$ were aphakics, surgical reattachment was obtained in $96,4 \%$ of cases. Similarly, 40 to $50 \%$ of patients with macular detachment achieve acuity of $20 / 50$ or better postoperatively. ${ }^{23,24,27,28}$ In the present study, all the patients had macular detachment at presentation and post operative visual acuity of $6 / 36$ or better was achieved in $52.7 \%$.

\section{CONCLUSIONS}

The study has shown a promising result for the retinal detachment surgery. We need to have a large size study to support this finding. Development of infrastructure is a must.

\section{ACKNOWLEDGEMENTS}

We would also like to appreciate the effort of $\mathrm{Mr}$. Mukunda Wagle in computer works and Nepal Eye Hospital staffs.

\section{REFERENCES}

1. Kanski JJ. Clinical Ophthalmology. 5th ed. USA: utterworthHeinemann; 2004. P.353-88.

2. Gonin J. Le traitementdu ecollement etinien. Ann Ocul (Paris). 1921;158:175-194.

3. Deutschmann R. Ueber zwei Verfahren bei Behandlungder Netzhautabloesung nebst Bemerkungen Zur Genese des Netzhautrisses und seines Verhaeltnisses zur Entstehung der Abloesung. Klin Monatsbl Augenheilkd. 1933;91:450-6.

4. Krawawicz T. Intracapsular extraction of intumescent cataract by application of low temperature. Br J Ophthalmol. $1961 ; 45: 279-83$

5. Michels RG, Wilkinson CP, Rice TA. Retinal detachment. St. Louis: CV Mosby; 1990.p.294-7.

6. Joan Miller J, Azar D, Blodi B. Albert \& Jakobiec's Principles \& Practice of Ophthalmology; vol 3. 3rd ed. USA: Saunders; 2008. p. 2359-75.

7. Hilton GF, Grizzard WS. Pneumatic retinopexy. A twostep outpatient operation without conjunctival incision. Ophthalmology. 1986 May;93(5):626-41.

8. HIlton GF, Kelly NE, Salzano TC, et al: Pneumatic retinopexy: A collaborative report of first 100 cases. Ophthalmology. 1987;94:307-14.

9. Tornambe PE, HIlton GF, Kelly NF, et al. Expanded indications for pneumatic retinopexy. Ophthalmology. 1988;95:597-600.

10. Lincoff HA, Kreissig I, Hahn YS. A temporary balloon buckle for the treatment of small retinal detachments. Ophthalmology. 1979 Apr;86(4):586-96.

11. Wong TY, James MT, Oliver DS, et al. Racial difference in the incidence of retinal detachment in Singapore. Arch Ophthalmol. 1999;117:379-83.

12. Johnathan AR, Jay CE, Keith HB, et al. Retinal detachment in Olmsted County, Minnesota, 1976 through 1995. Ophthalmology. 1999;106:154-9.

13. Haimann NH, Burton TC, Brown CK. Epidemology of retinal detachment. Arch of Ophthalmol. 1982;100:289-92.

14. Comer MB, Newman DK, Martin KR, et al. Who should manage retinal detachments. Eye. 2000;14,572-8.
15. Wang NK, Chen TL, Lai CC, Kuo YH, Chao AN, Wu WC, et al. Clinical characteristics and surgical outcomes of pediatric retinal detachments with lens disorders. J Pediatr Ophthalmol Strabismus. 2009 May-Jun;46(3):160-7.

16. Thompson JA, Snead MP, Billington BM, et al. National audit of the outcomes of primary surgery for rhegmatogenous retinal detachment. Eye. 2002;16:771-7.

17. Johnson Z, Ramsay A, Cottrell D, et al. Triple cycle audit of primary retinal detachment surgery. Eye. 2002;16(5):513-8.

18. Yorston D, Jalali S. Retinal detachment in developing countries. Eye. 2002;16:353-8.

19. Lewis H, Haberg TM, Abrams GW. Causes of failure after initial V_R Surgery for Severe PVR. AMJ Ophthalmol. 111;8(14):1991.

20. American Academy of Ophthalmology. Retina and vitreous [Online]. [cited 2008 Dec 10]. Available from: URL:http:// one.aao.org

21. Ed Pasrisha JK, editor. Retina. India: India Ophthalmological Society :1998.

22. Tani P, Robertson DM, Langworthy A. Prognosis for central vision and anatomic reattachment in rhegmatogenous retinal detachment with macula detached. Am J Ophthalmol. 1981 Nov;92(5):611-20.

23. Salicone A, Smiddy WE, Venkatraman A, et al. Visual recovery after scleral buckling procedure for retinal detachment. Ophthalmology. 2006 Oct;113(10):1734-42.

24. Mc Pherson AR, O'MalleyRE, Butner RW, et al. Visual acuity after surgery for retinal detachment with macular involvement. Ann Ophthalmol. 1982;14:639-45.

25. Norton EWD. Retinal Detachment in aphakia. Trans Am Ophthalmol Soc. 1963;61:770-89.

26. O'Connor PR. External buckling without drainage for selected detachments inaphakiceyes. AmJOphthalmol. 1976;82:358-64.

27. Grupposo SS. Visual acuity following surgery for retinal detachment. Arch Ophthalmol. 1975;93:327-30.

28. Davidorf FH, Havener WH, Lang JR. Macular vision following retinal detachment surgery. Ophthalmic Surg. 1975;6(4):74-81. 